\title{
Soil Microbial Biomass and Fungi Reduced With Canola Introduced Into Long-Term Monoculture Wheat Rotations
}

\author{
Jeremy C. Hansen ${ }^{1 *}$, William F. Schillinger ${ }^{2}$, Tarah S. Sullivan ${ }^{2}$ and Timothy C. Paulitz ${ }^{3}$ \\ ${ }^{1}$ Northwest Sustainable Agroecosystems Research Unit, USDA-Agricultural Research Service, Washington State University, \\ Pullman, WA, United States, ${ }^{2}$ Department of Crop and Soil Sciences, Washington State University, Pullman, WA, \\ United States, ${ }^{3}$ Wheat Health, Genetics, and Quality Research Unit, USDA-Agricultural Research Service, Washington State \\ University, Pullman, WA, United States
}

\section{OPEN ACCESS}

Edited by:

Saskia Bindschedler, Université de Neuchâtel,

Switzerland

Reviewed by: Jincai Ma,

Jilin University, China

Margot Schulz,

University of Bonn, Germany Lauren Hale,

University of Oklahoma, United States

${ }^{*}$ Correspondence: Jeremy C. Hansen hansenjc@wsu.edu

Specialty section:

This article was submitted to Terrestrial Microbiology, a section of the journal Frontiers in Microbiology

Received: 29 January 2019 Accepted: 14 June 2019 Published: 11 July 2019

Citation: Hansen JC, Schillinger WF Sullivan TS and Paulitz TC (2019) Soil Microbial Biomass and Fungi Reduced With Canola Introduced Into Long-Term Monoculture Wheat Rotations.

Front. Microbiol. 10:1488 doi: 10.3389/fmicb.2019.01488
With increasing canola (Brassica napus L.) acreage in the Inland Pacific Northwest of the USA, we investigated the effect of this relatively new rotational crop on soil microbial communities and the performance of subsequent wheat (Triticum aestivum L.) crops. In a 6-year on-farm canola-wheat rotation study conducted near Davenport, WA, grain yields of spring wheat (SW) following winter canola (WC) were reduced an average of 17\% compared to SW yields following winter wheat (WW). Using soil samples collected and analyzed every year from that study, the objective of this research was to determine the differences and similarities in the soil microbial communities associated with WC and WW, and if those differences were associated with SW yield response. Microbial biomass and community composition were determined using phospholipid fatty acid analysis (PLFA). The WC-associated microbial community contained significantly less fungi, mycorrhizae, and total microbial biomass than WW. Additionally, reduced fungal and mycorrhizal abundance in SW following WC suggests that the canola rotation effect can persist. A biocidal secondary metabolite of canola, isothiocyanate, may be a potential mechanism mediating the decline in soil microbial biomass. These results demonstrate the relationship between soil microbial community composition and crop productivity. Our data suggest that WC can have significant effects on soil microbial communities that ultimately drive microbially mediated soil processes.

Keywords: Brassica napus L, crop rotation, soil microbial communities, phospholipid fatty acid analysis, wheat

\section{INTRODUCTION}

Soil microorganisms are an integral part of many soil processes in agroecosystems. The soil microbial community plays a key role in aggregate stability (Duchicela et al., 2013; Graf and Frei, 2013), mineralization and stabilization of organic matter (Lützow et al., 2006; Schmidt et al., 2011), nutrient cycling (Kennedy and Papendick, 1995; Talbot et al., 2013), soil ecological function, and biological stability (Griffiths and Philippot, 2013). These processes can be altered by shifts in the activity and composition of microbial communities caused by environmental 
conditions or agricultural practices. Soil microbial communities are sensitive to changes in tillage (Larkin and Honeycutt, 2006), cover cropping (Pritchett et al., 2010), soil amendments (Marschner et al., 2003; Tian et al., 2015), soil moisture (Kennedy and Schillinger, 2006; Brockett et al., 2012), and temperature (Petersen and Klug, 1994; Bossio et al., 1998). However, no single agricultural input or management strategy imposed on a soil determines the composition of the microbial community. Rather, a combination of edaphic and dynamic factors, including crop rotation, residue management, soil type, tillage, and climate, all interact to influence the microbial community (Bünemann et al., 2008; Gil et al., 2011; Zhang et al., 2014).

Agroecosystems with generally well-defined histories often have controlled inputs that directly influence soil microbial communities (Minoshima et al., 2007; Buyer et al., 2010). In soils with such histories, above-ground changes in crop species (Grayston et al., 1998; Marschner et al., 2001; Ladygina and Hedlund, 2010), crop rotation sequence (Alvey et al., 2003; Bünemann et al., 2008; Schillinger et al., 2010; Xuan et al., 2012), and tillage (Schillinger et al., 2007; Gil et al., 2011; Zhang et al., 2014) will influence below-ground physical and biological properties. Agricultural soils of the dryland cropping regions of the Pacific Northwest have historically been used to produce wheat in 2- or 3-year rotations (Schillinger et al., 2006).

Crop rotation has been well documented as a driving factor influencing soil microbial community composition (Drijber et al., 2000; Larkin and Honeycutt, 2006; Xuan et al., 2012; Valetti et al., 2016). Soil fungal (Zhang et al., 2014; Valetti et al., 2016) and bacterial communities are influenced by crop rotation (Alvey et al., 2003; Larkin and Honeycutt, 2006; Xuan et al., 2012) and will vary with different crops in a rotation sequence (Grayston et al., 1998; O'Donnell et al., 2001). An increase in the frequency of oilseed rape (Brassica napus) in wheat-oilseed-based rotations is reported to significantly affect soil fungal communities (Hilton et al., 2013). Reduced diversity among soil fungal and rhizosphere bacterial communities associated with Brassica plants has also been observed (Bennett et al., 2014).

Knowledge of how plant-derived phytochemicals influence soil microbiota through positive or negative root-soil interactions is increasing (Bais et al., 2006; Kong et al., 2008; Lorenzo et al., 2013). Phytochemicals released in root exudates and through decomposition of residues have enormous potential to affect soil microbial community composition and structure (Dong et al., 2014). Glucosinolates (GSLs) and isothiocyanates (ITCs) of Brassica plant species are phytochemicals of interest due to their biofumigation potential (Brown and Morra, 1997; Rumberger and Marschner, 2003; Matthiessen and Kirkegaard, 2006). The preferred method of biofumigation for soil-borne pathogen suppression is through incorporation of Brassica green manure crops or seed meal (Brown and Morra, 1997; Morra and Kirkegaard, 2002; Matthiessen and Kirkegaard, 2006; Mazzola et al., 2015). Biocidal compounds (ITCs) of Brassica seed meal drastically reduced soil fungal populations, while ITC amendments caused a shift in the fungal community composition (Hu et al., 2015). As a rotational crop, however, the seed is harvested and the residue material is left on the soil surface, rather than incorporated. Therefore, any influence on soil microbial communities relies on GSLs, ITCs, or other compounds released through leaf washings (Walsh et al., 2014), root exudates (Marschner et al., 2001), or detached root material (Bennett et al., 2014).

The GSL gluconasturtiin of canola roots (Sarwar et al., 1998) hydrolyzes to form 2-phenylethylisothiocyanate and is released by living canola roots into the surrounding soil (Rumberger and Marschner, 2003). Root GSL and ITC concentration is elevated compared to the above-ground leaf and shoot material and is in direct contact with rhizosphere microorganisms (van Dam et al., 2009). Exudation of ITC from canola roots is sufficient to effectively suppress some soil-borne pathogens (Haramoto and Gallandt, 2004) and reduce specific soil microorganisms within the active portion of the soil microbial community (Smith and Kirkegaard, 2002; Rumberger and Marschner, 2003). Recently, Lay et al. (2018) observed significant differences in the rhizosphere microbiome of canola compared to wheat. Changes in the soil microbial community composition of wheat have been attributed to the influence of the preceding oilseed rape crop (Hilton et al., 2018). Therefore, canola as a rotational crop could induce changes in the soil microbial community composition (Smith et al., 2004; Valetti et al., 2016; Hilton et al., 2018).

Critical microbial processes that could be disrupted by exposure to the hydrolysis products of GSLs include nitrification, nitrogen fixation, and plant-microbial symbiotic associations (Haramoto and Gallandt, 2004). Free-living nitrogen-fixing bacteria populations were reported to be lower following a canola crop (Kirkegaard and Sarwar, 1999). Total abundance of ammonium-oxidizing and nitrite-oxidizing bacteria populations were reduced and nitrification capacity decreased by $35-65 \%$ after exposure to ITCs, while 2-phenylethylisothiocyanate completely inhibited nitrification (Bending and Lincoln, 2000). Abundance of arbuscular mycorrhizae (AM fungi) declined by approximately $60 \%$ after a 28 -day exposure to rape seed extract ITC (Siebers et al., 2018), and mycorrhizal hyphae were negatively influenced by Brassica root exudates (Koide and Schneider, 1992). Reduced wheat yields in plots previously planted to canola were attributed to poor colonization with AM fungi, indicated by a significant correlation between yield of wheat and the levels of AM fungi (Owen et al., 2010).

In a 6-year on-farm rotation study conducted near Davenport, $\mathrm{WA}$, yield data were collected for both WC and WW at harvest of plots in the first year of the crop sequence. In the second year of the crop sequence, yield data were collected for SW following both WC and WW. Schillinger and Paulitz (2018) reported that the average yield for WC and WW was 2,603 and $6,375 \mathrm{~kg} \mathrm{ha}^{-1}$, respectively. Schillinger and Paulitz (2018) further reported that average SW grain yield following WC and WW was 3,267 and 3,932 $\mathrm{kg} \mathrm{ha}^{-1}$, respectively. Spring wheat yields were significantly greater after WW compared to WC in 3 of the 5 years. The 5 -year average yield for SW after WC was significantly $(p<0.0001)$ reduced by $17 \%$ compared with SW after WW. Averaged over the years, there were no differences in soil water use or soil water content between WC and WW at time of planting of SW 
(Schillinger and Paulitz, 2018). There were no visible or measurable foliar or root diseases in any crop in any year, nor were any root lesion nematodes detected (Schillinger and Paulitz, 2018). All plots were essentially weed-free every year. All plots were adequately fertilized. Schillinger and Paulitz (2018) concluded that unidentified factors caused the significant $17 \%$ yield reduction of SW following WC vs. WW and suspected this difference could be related to soil microbiology. This generated the interest and focus of the current study for an in-depth microbiological analysis of the soil cores collected and archived every year from the study.

Phospholipid fatty acid (PLFA) analysis is frequently used to assess the composition of microbial communities in agricultural soils (Finney et al., 2017). Microbial community PLFA analysis provides sensitive, reproducible measurements to explore the soil microbial community resulting in estimates of both microbial community composition and biomass (Kaur et al., 2005). Bacterial and fungal cell walls are composed of phospholipids that rapidly degraded after cell death and therefore represent a reliable in situ, quantitative measure for living microorganisms in soil (Kaur et al., 2005; Pollierer et al., 2015). Data from phospholipid analysis represent the viable microbial biomass, whereas DNA sequencing techniques may include relic DNA from deceased microbial cells that have been exposed to ITC (Siebers et al., 2018). While other molecular methods can deliver a more detailed description of microbial diversity, PLFA offers the advantage of quantifying the total microbial biomass at a lower cost (Finney et al., 2017). When comparing PLFA profiling to $16 \mathrm{~S}$ rRNA gene metabarcoding, Orwin et al. (2018) determined the two techniques to give broadly comparable results for detecting changes in community composition and ecosystem functions. PLFA profiling is a powerful tool to monitor changes in microbial communities (Buyer and Sasser, 2012; Zhang et al., 2014) and is widely used to investigate microbial community dynamics during land-use change (Smith et al., 2015).

The objective of our study was to examine the short-term influence of canola as a rotational crop on soil microbial communities that have developed under traditional wheat monoculture rotations. The study was initiated on land that had been in monoculture cereal production for 140 years and managed using direct seeding (i.e., no-till) for 15 years in a 3-year WW-SW-NTF (no-till summer fallow) rotation. Canola or any other broadleaf crop had never been previously grown on this land. Long histories and consistent rotations allow for a pseudo isolation of variables and the ability to focus on the effects of canola on subsequent wheat crops. We hypothesized that the canola-associated soil microbial community would be differentially influenced by exposure to residues of canola plants and particularly exudates of canola roots. More specifically, we hypothesized that exposure to residues of winter canola plants and particularly exudates of canola roots will shift the soil microbial community, compared to a previous rotation of winter wheat. PLFA analysis coupled with microbial enzyme activities could increase the current knowledge of the presence of canola-associated exudates and residues in soil and the relative impact on the corresponding soil microbial communities.

\section{MATERIALS AND METHODS}

\section{Site Description and Experimental Design}

A 6-year on-farm crop rotation experiment was conducted during the 2008-2013 crop years at the Hal Johnson farm $\left(47^{\circ} 40^{\prime} 16.86^{\prime \prime} \mathrm{N} 118^{\circ} 1^{\prime} 58.87^{\prime \prime} \mathrm{W}\right)$ located $9 \mathrm{~km}$ east of Davenport, WA. Long-term annual precipitation at the site averages $432 \mathrm{~mm}$. Crop-year (September 1 to August 31) precipitation during the study period ranged from 342 to $510 \mathrm{~mm}$ and averaged $396 \mathrm{~mm}$ during the 6-year experiment.

The soil is a Hanning silt loam (fine-silty, mixed, superactive, and mesic pachic argixerolls) with $0-7 \%$ slopes and a depth of 1.5-2 $\mathrm{m}$ to restrictive layers (NRCS, 2018). The experimental crop rotations were WC-SW-NTF compared with the traditional WW-SW-NTF. This resulted in four distinct treatment conditions for our study: (1) WC, (2) WW, (3) SW following WC (SW-WC), and (4) SW following WW (SW-WW). In the 140-year farming history of this land, only cereal crops have been grown (i.e., no Brassica or other broadleaf crops). Since the WC and WW were established on different land parcels each year, the WC was always planted into "virgin" canola soil. All crops were direct-seeded (without tillage, to maintain the no-till management) into the standing stubble of the previous crop with a hoe-opener drill with $10 \mathrm{~cm}$ paired rows on $30 \mathrm{~cm}$ row spacing. The drill was equipped to apply liquid fertilizer in a deep band between the paired rows.

Experimental design was a randomized complete block with six replications. Individual plot size was $30 \mathrm{~m} \times 5 \mathrm{~m}$. Seeding rate for the three crops varied slightly each year and averaged 6,83 , and $100 \mathrm{~kg} \mathrm{ha}^{-1}$ for WC, WW, and SW, respectively. Fertilizer application rates of nitrogen $(\mathrm{N})$, phosphorous $(\mathrm{P})$, and sulfur (S) were based on soil test results. Winter canola and $\mathrm{WW}$ have similar $\mathrm{N}$ and $\mathrm{P}$ requirements, but $\mathrm{WC}$ has a greater S requirement than WW (Koenig, 2005). Therefore, the $S$ fertilizer applied each year was based on the needs of WC. Both WC and WW always received identical rates of $\mathrm{N}$, $\mathrm{P}$, and $\mathrm{S}$ fertilizer. Soils in the region contain naturally high quantities of potassium $(\mathrm{K})$ and that nutrient was not applied. Fertilizer was applied in several different combinations over the years by coulter injection in late summer and in the spring as well as at time of planting of WC, WW, and SW.

Winter canola and WW were planted prior to September 15, and SW was planted in late April-early May. Details of seeding rates, cultivars, plant stands, fertilizers, and herbicides used throughout the experiment are provided in Schillinger and Paulitz (2018). Crops in all plots were maintained essentially weed-free. Winter canola was lost to freezing damage in 2010; thus, the experiment was abandoned that year. Since SW follows winter crops in this rotation, no SW data could be collected in 2011 .

\section{Soil Sampling}

Soil samples for microbial analyses were collected from 0 to 5,5 to 10 , and 10 to $15 \mathrm{~cm}$ depths to account for stratified soil properties often produced in long-term no-till systems. Soil was sampled from all plots in mid-May, when WW was tillering, WC was at inflorescence emergence, and SW seedlings 
were newly emerged. From each replicated plot, seven $3.0-\mathrm{cm}$-diameter soil cores at each depth were combined to form a composite sample. The seven cores were collected randomly across the length and width of each plot, avoiding borders. Sample collection occurred each year at the same time from 2009 through 2015. Samples collected in the first year of the rotation were from WC and WW. Samples from the subsequent year were collected from SW following WC (SW-WC), and SW following WW (SW-WW) resulting in four treatment combinations. After collection, samples were immediately transported on ice in the dark to the USDA laboratory located in Pullman, WA. Subsamples of the composite soil were collected in sterile tubes and stored at $-80^{\circ} \mathrm{C}$ until analysis.

\section{Soil Chemical Analyses}

Soil pH and electrical conductivity (EC) were determined as outlined in McLean (1982). A soil slurry of 1:1 soil to distilled, deionized water was prepared and allowed to mix overnight by end-over-end shaking at $40 \mathrm{rpm}$. After shaking, the slurry was then centrifuged at $2,831 \times g$, and the resulting supernatant was measured. Soil solution $\mathrm{pH}$ was measured with an Orion Research 811 (Boston, MA) pH meter, and EC was measured using a digital conductivity meter (VWR International, Bristol, CT).

\section{Soil Microbial Enzyme Activity}

As indicators of microbial activity, soil $\beta$-glucosidase (BGA) and dehydrogenase (DEA) were determined as described in Tabatabai and Dick (2002). Colorimetric measurement, and calculation of p-nitrophenol (PNP) and 2,3,5-triphenyl formazan (TPF) are described in Hansen et al. (2018). Briefly, colorimetric measurements of extracted solutions were completed on a BioTek microplate reader (BioTek, Winooski, VT), set to a wavelength of $410 \mathrm{~nm}$ (BGA), and $492 \mathrm{~nm}$ (DEA). Results for BGA are expressed in micrograms of p-nitrophenol (PNP) released per gram of dry soil per hour, while DEA is expressed as micrograms of 2,3,5-triphenyl formazan (TPF) per gram of dry soil per hour.

\section{Soil Microbial Biomass and Community Composition}

The protocol described by Buyer et al. (2010) was followed for PLFA extraction. Lyophilized soil (2.5 g) was extracted according to Bligh-Dyer extraction (Bligh and Dyer, 1959), with $12 \mathrm{ml}$ of extractant as described by Petersen and Klug (1994). Lipid separation was completed with a solid-phase extraction column. Phospholipids were eluted with $5 \mathrm{ml}$ of methanol. After evaporation under $\mathrm{N}_{2}$, the phospholipids were transesterified to fatty acid methyl esters, extracted into $4 \mathrm{ml}$ of hexane, and evaporated. Phospholipids were analyzed on an Agilent 6890 GC equipped with autosampler, splitsplitless injector, Agilent Ultra 2 column, and flame ionization detector. The GC was controlled with Agilent Chemstation and MIDI Sherlock software (Microbial ID, Inc., Newark, DE, USA). Hydrogen was used as the carrier gas at $66.9 \mathrm{kPa}$ constant pressure. The split ratio of the MIDI Eukaryote method was changed from 1:100 to $1: 50$ to increase sensitivity. The initial oven temperature was $170^{\circ} \mathrm{C}$ and programmed to ramp at $5^{\circ} \mathrm{C} \mathrm{min}^{-1}$, with a final hold of $12 \mathrm{~min}$ at $300^{\circ} \mathrm{C}$. An internal standard of 19:0 nonadecanoic acid methyl ester was used for quantification. Peak chromatographic responses for fatty acids were converted to molarity by reference to the internal standard 19:0 Methyl nonadecanoate (SigmaAldrich Inc., St. Louis, MO, USA). Peak areas of carbon chain lengths between 12:0 and 20:0 were summed into biomarker groups (Hansen et al., 2018). Iso and anteiso branched fatty acids were used as biomarkers for Grampositive (Gram+) bacteria (Zelles, 1999). Gram-negative bacteria (Gram-) were identified by monounsaturated fatty acids, and cyclopropyl 17:0 and 19:0 (Zelles, 1997). The fatty acids 18:2 $\omega 6 \mathrm{c}$ and 18:1 $\omega 9$ were used as biomarkers for fungi (Vestal and White, 1989; Frostegård and Bååth, 1996; Bååth, 2003). Arbuscular mycorrhizae (AM fungi) biomarker included 16:1 $\omega 5 \mathrm{c}$ (Olsson, 1999) and 20:1 $\omega 9 \mathrm{c}$ (Madan et al., 2002). Total of all PLFA biomarkers (T-PLFA) was considered the viable microbial biomass.

\section{Statistical Analysis}

Analysis of variance (ANOVA) was conducted for soil chemical, enzyme activity, and microbial biomarker data using a randomized complete block design with a one-way treatment structure ANOVA. Differences were assessed using linear mixed models (PROC MIXED SAS version 9.4; SAS Inc., Cary, NC) with treatment as the fixed-effect factor and year as the random-effect factor. To determine significant differences between treatment means, comparisons were performed through the GLMIMIX procedure at $p \leq 0.05$. When $p$ 's indicated significance, differences in treatment means were determined by Fisher's protected LSD. Multivariate discriminant function analysis using the linear common covariance method (JMP, 1989-2007) was used to explore the primary effect of the crop treatment on the structure of the soil microbial community. This analysis maximizes the among-group variation relative to the within-group variation to identify differences between previously established groups (Lazcano et al., 2013). Linear discriminant analysis uses canonical plots to display the multivariate means of each group in the two dimensions that best differentiate the microbial communities. Bi-plots of the first two canonical variables illustrate the two dimensions that create maximum separation of microbial communities associated with each crop treatment. For clarity, the group means are shown and not individual points $(n=120)$. Each point is accompanied by a mean ellipse at the $95 \%$ confidence interval. By definition, two groups are significantly different from each other when the ellipses do not intersect (JMP, 1989-2007). The bi-plot vectors represent covariates (biomarker groups), with the length and direction of each vector proportional to the degree of association with the first two canonical variates. For all bi-plot presented in this paper, the first canonical variate $(\mathrm{CV})$ accounts for the bulk the variance. Therefore, separations along the horizontal axis are more significant than those occurring along the vertical axis. Analysis was performed 
using the JMP software program (JMP, 1989-2007) at the $p \leq 0.05$ significance level.

\section{RESULTS}

\section{Soil Properties and Enzyme Activities}

Crop rotation did not have a significant effect on the soil $\mathrm{pH}$, EC, or gravimetric water content, which averaged $5.30( \pm 0.11)$ and $5.33( \pm 0.14), 97.90( \pm 1.97)$, and $96.59( \pm 1.49) \mu \mathrm{S} \mathrm{cm} \mathrm{cm}^{-1}$, and $0.20 \pm 0.09$ and $0.21 \pm 0.11 \mathrm{~kg} \mathrm{~kg}^{-1}$ for the WC and WW, respectively. Activity levels of DEA did not exhibit a consistent pattern of significant differences throughout the experiment (Figure 1A). Differences were observed in 2008 between WC and WW, and 2013 between SW-WW and SW-WC at $0-5 \mathrm{~cm}$. Data for BGA did, however, exhibit significant differences between treatments at $0-5 \mathrm{~cm}$ (Figure 1B). In the winter-crop cycle of the crop sequence, BGA was greater in WW than in WC in all five crop years. For the ensuing SW, BGA was significantly greater in SW-WW vs. SW-WC in three of the five crop years. Consistent differences in enzyme activity at the 5-10 and $10-15 \mathrm{~cm}$ depths were not observed (data not shown).

\section{Soil Microbial Biomass and Community Composition}

The absolute abundance of microbial lipid biomarkers in the $0-5 \mathrm{~cm}$ depth for fungi, AM fungi, and total viable microbial biomass (T-PLFA) were significantly greater in WW compared to WC when averaged across the duration of the experiment (Table 1). Similar decreases in biomarkers associated with SW-WC were detected in the second year of the rotation. Both fungi and AM fungi were significantly less in SW-WC compared to SW-WW (Table 1). Likewise, abundance of biomarkers was greater in WW compared to WC at the 5-10 cm depth in the first year of the rotation (Table 1). Significant reductions in fungi, AM fungi, and TPLFA were seen in WC at this depth. However, bacteria did not differ (Table 1). Differences in individual lipid biomarkers and T-PLFA were not observed at the $10-15 \mathrm{~cm}$ depth in either the first year WC and WW treatments, or the following SW-WC and SW-WW treatments (Table 1).

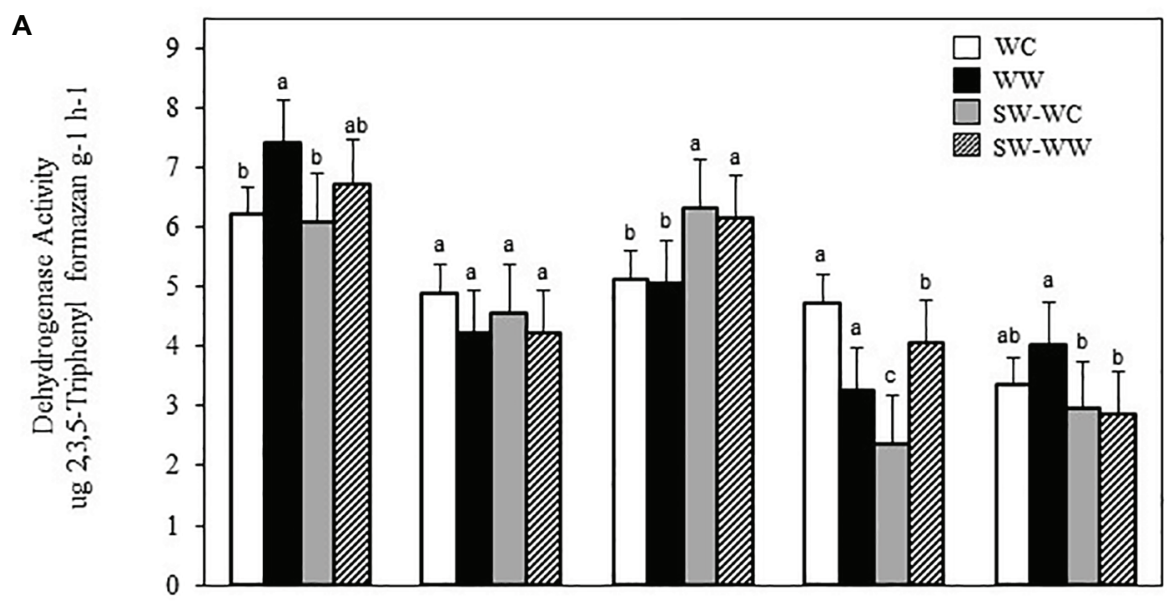

B

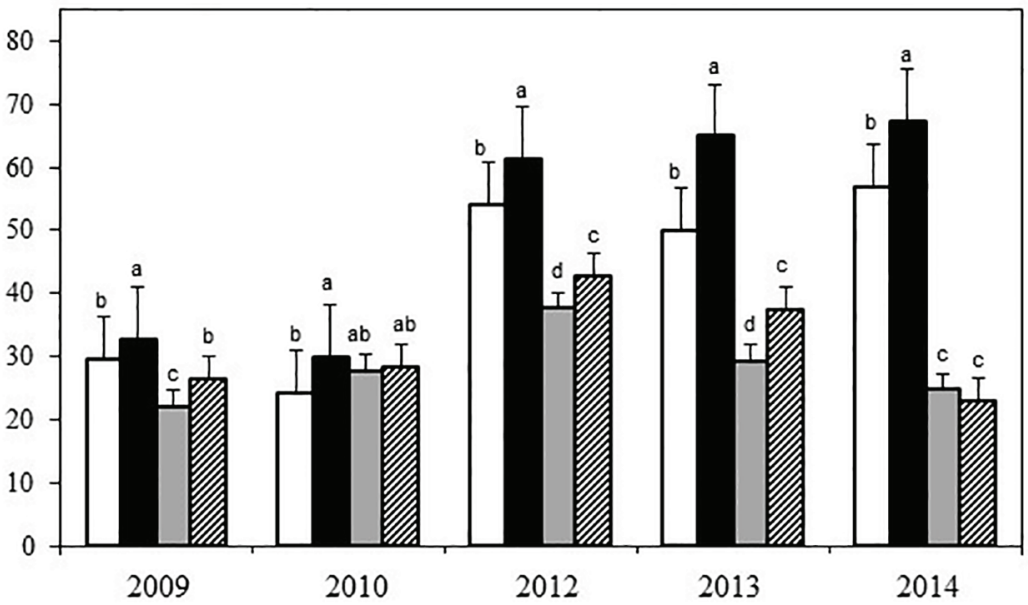

FIGURE 1 | Dehydrogenase activity (A), and $\beta$-glucosidase activity (B), under different crop treatments from 2009 to 2014 at 0-5 cm. Error bars represent standard error. Different letters within years indicate significant differences at $p<0.05$. 
TABLE 1 | Absolute abundance (nmol/g) of microbial lipid groups at 0-5, 5-10, and 10-15 cm depths from crop years 2009-2014.

\begin{tabular}{|c|c|c|c|c|c|c|}
\hline Depth & Treatment & Fungi & AM fungi & Gram- & Gram+ & Total \\
\hline \multirow[t]{4}{*}{$0-5 \mathrm{~cm}$} & WC & 1.11 B & 0.22 B & 1.68 B & $3.01 \mathrm{AB}$ & $12.47 \mathrm{~B}$ \\
\hline & WW & $1.74 \mathrm{~A}$ & $0.41 \mathrm{~A}$ & $3.96 \mathrm{~A}$ & $3.66 \mathrm{~A}$ & 16.67 A \\
\hline & SW-WC & 0.98 B & 0.18 B & $1.18 \mathrm{~B}$ & $2.69 \mathrm{~B}$ & $11.32 \mathrm{~B}$ \\
\hline & SW-WW & $1.60 \mathrm{~A}$ & $0.34 \mathrm{~A}$ & 1.32 B & $3.12 \mathrm{AB}$ & $13.32 \mathrm{~B}$ \\
\hline \multirow[t]{4}{*}{$5-10 \mathrm{~cm}$} & WC & 0.52 B & $0.10 \mathrm{~B}$ & $0.84 \mathrm{AB}$ & $1.56 \mathrm{AB}$ & 8.55 B \\
\hline & WW & $0.80 \mathrm{~A}$ & $0.18 \mathrm{~A}$ & $1.05 \mathrm{~A}$ & $1.83 \mathrm{~A}$ & $9.95 \mathrm{~A}$ \\
\hline & SW-WC & $0.36 \mathrm{C}$ & $0.04 \mathrm{C}$ & $0.62 \mathrm{BC}$ & $1.36 \mathrm{~B}$ & 8.27 B \\
\hline & SW-WW & $0.51 \mathrm{D}$ & $0.12 \mathrm{D}$ & $0.55 \mathrm{C}$ & 1.25 B & 7.76 B \\
\hline \multirow[t]{4}{*}{$10-15 \mathrm{~cm}$} & WC & $0.49 \mathrm{~A}$ & $0.08 \mathrm{~A}$ & 0.93 A & $1.60 \mathrm{~A}$ & 3.94 A \\
\hline & WW & $0.49 \mathrm{~A}$ & $0.09 \mathrm{~A}$ & 0.83 A & $1.59 \mathrm{~A}$ & $3.77 \mathrm{~A}$ \\
\hline & SW-WC & $0.54 \mathrm{~A}$ & $0.07 \mathrm{~A}$ & $0.79 \mathrm{~A}$ & $1.46 \mathrm{~A}$ & $3.75 \mathrm{~A}$ \\
\hline & SW-WW & $0.59 \mathrm{~A}$ & $0.08 \mathrm{~A}$ & $0.83 \mathrm{~A}$ & $1.53 \mathrm{~A}$ & $3.84 \mathrm{~A}$ \\
\hline
\end{tabular}

Values are least square means $(n=120)$ across all years. Means within a column at each depth with different letters are significantly different ( $p \leq 0.05)$. Bold italics indicate significant differences between WC and WW, or SW-WC and SW-WW.

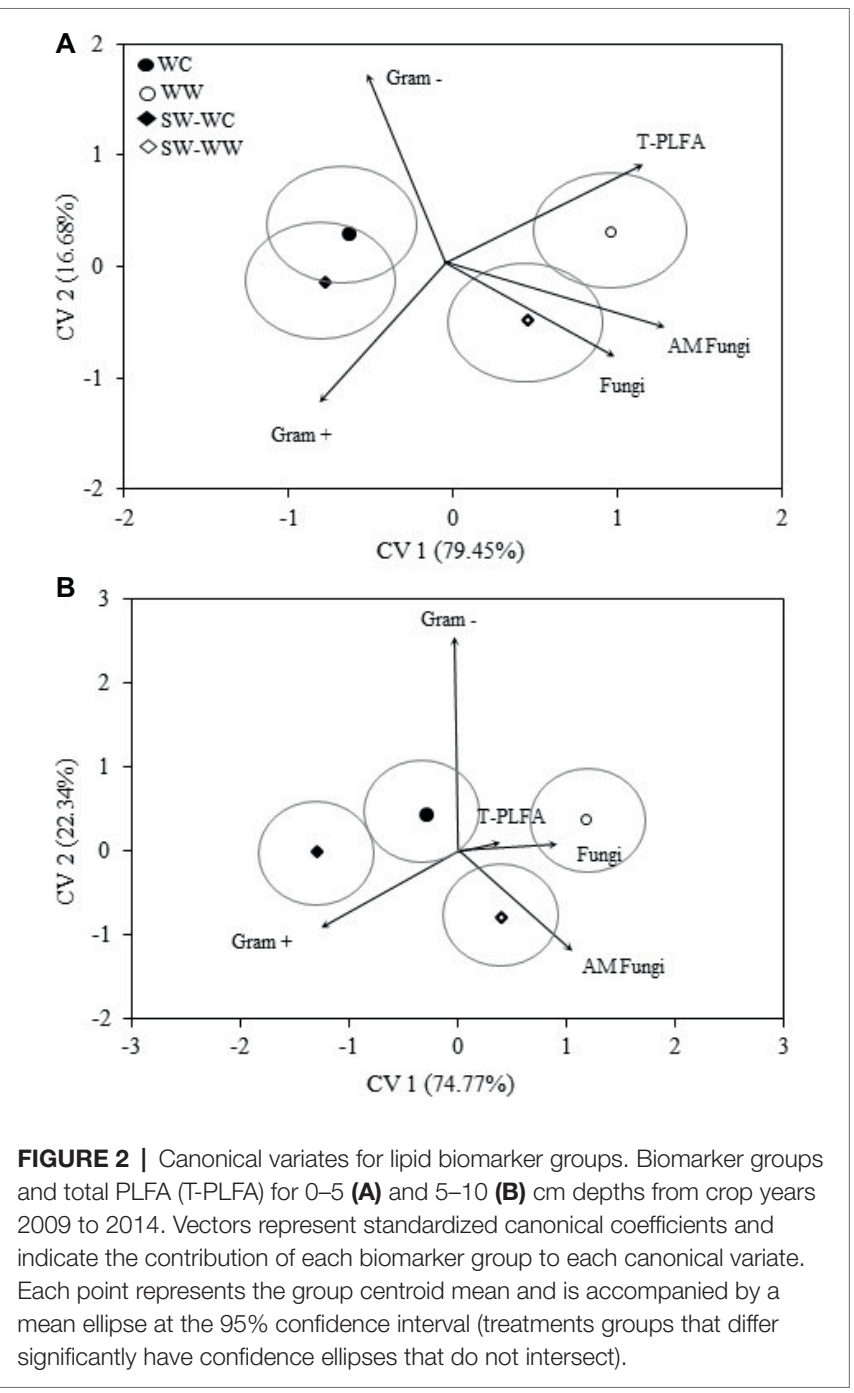

Discriminant analysis for the microbial biomarkers averaged across all years is represented as bi-plots in Figure 2. For both the $0-5$ and $5-10 \mathrm{~cm}$ depths, the microbial communities associated with WC and WW are distinct from one another.
Separation associated with CV1 indicates the greatest differences exist between the WC and WW treatments. Both WW and SW-WW are positively correlated with CV1, whereas WC and SW-WC are negatively correlated. The discriminant functions associated with CV1 and CV2 accounted for 79 and $16 \%$ of the variance for a total explained variance of $96 \%$ at the 0-5 cm depth (Figure 2A). At the 5-10 cm depth, CV1 and CV2 accounted for 74 and 22\%, combining for a total explained variance of $97 \%$ (Figure 2B). Because CV1 accounts for the bulk of the variance, the mean ellipse of WW at the $0-5 \mathrm{~cm}$ depth shows significant difference from those of WC and SW-WC, while the ellipses of WC and SW-WC indicate the greatest similarities (Figure 2A). Similarly, the greatest differences at the 5-10 cm depth are between WW and both WC and SW-WC.

The magnitude and positive correlation to both CV1 and CV2 in the surface soil suggest that T-PLFA has the greatest influence on the community associated with WW. The communities associated with SW-WW appear to be strongly influenced by fungi and AM fungi. At 5-10 cm, AM fungi appear to be largely responsible for the separation of SW-WW, while fungi and T-PLFA align with the community of WW. Differentiation between the microbial communities of WC, WW, SW-WC, and SW-WW based on the amounts and types of PLFAs was significant at $p<0.05$. At the $0-5$ and $5-10 \mathrm{~cm}$ depth, CV1 discerned WC vs. WW and SW-WC vs. SW-WW (Table 2). Canonical variate 2 discriminated WC vs. SW-WC, and WW vs. SW-WW.

The absolute abundance of microbial lipid biomarkers is reported for each crop year at the $0-5 \mathrm{~cm}$ depth in Table 3. The observed pattern, though not always significant, indicates greater microbial biomass for all lipid groups and T-PLFA in WW vs. WC and SW-WW vs. SW-WC. Notable differences in abundance occur among AM fungi in the winter-crop cycle of the crop sequence where AM fungi are significantly greater in WW compared to WC in two of the 5 years with the other crop years following the same trend. Furthermore, abundance of AM fungi in the spring-crop cycle of the crop sequence was significantly greater in SW-WW vs. SW-WC in three of the five crop years (Table 3). Among crop years, the 
abundance of all microbial lipid groups in 2012 was significantly greater in WW vs. WC, apart from fungi. Additionally, the abundance of all microbial lipid groups in 2013 was significantly greater in WW and SW-WW treatments over WC and SW-WC except for fungi in WC vs. WW, and Gram- in SW-WC vs. SW-WW (Table 3).

Discriminant analysis of microbial biomarkers for each crop year at the $0-5 \mathrm{~cm}$ depth is presented in Figure 3. In crop year 2009, the bi-plot reveals distinct separation of WC and WW treatments from SW-WC and SW-WW treatments along CV1 (76\%). SW-WC and SW-WW separated along CV2 (23\%), with mean ellipses sharing very little overlap (Figure 3A). The vectors for Gram+ and AM fungi were positively correlated with CV1, and total PLFA correlated with CV2. The community

TABLE 2 | Structure matrix (pooled within canonical structure) and biomarker means (group centroid) for the WC-WW-SW cropping sequence at the 0-5 and 5-10 cm depths.

\begin{tabular}{|c|c|c|c|c|}
\hline & \multicolumn{2}{|c|}{$0-5 \mathrm{~cm}$} & \multicolumn{2}{|c|}{$5-10 \mathrm{~cm}$} \\
\hline & CV 1 & CV 2 & CV 1 & CV 2 \\
\hline \multicolumn{5}{|c|}{ Structure loading } \\
\hline Fungi & 0.51 & -0.05 & 0.62 & 0.43 \\
\hline AM Fungi & 0.72 & 0.13 & 0.69 & 0.13 \\
\hline Gram- & 0.21 & 0.70 & 0.36 & 0.72 \\
\hline Gram+ & 0.26 & 0.27 & 0.22 & 0.49 \\
\hline Total & 0.56 & 0.55 & 0.29 & 0.53 \\
\hline \multicolumn{5}{|c|}{ Group centriods } \\
\hline WC & -0.63 & 0.30 & -0.30 & 0.44 \\
\hline WW & 0.96 & 0.32 & 1.18 & 0.38 \\
\hline SW-WC & -0.77 & -0.13 & -1.30 & -0.02 \\
\hline SW-WW & 0.45 & -0.48 & 0.40 & -0.79 \\
\hline
\end{tabular}

Bold italics indicate positive and negative correlations to the canonical variates. structure in 2010 showed significant differences between SW and the preceding crop (Figure 3B), with only small differences for WC vs. WW, and SW-WC vs. SW-WW. Compared to other crop years, 2010 was the only year where both SW-WC and SW-WW were positively correlated with CV1 (89\%) and associated with the vectors of AM fungi, T-PLFA, and Grambacteria. For crop year 2012, the first CV (94\%), discriminated WW from all other treatments, with SW-WW distinct from WC and SW-WC whose communities showed little differences. The vectors for T-PLFA and AM fungi correlated with both canonical variates (Figure 3C). The bi-plot for crop year 2013 discriminated WC and SW-WC from WW and SW-WW along CV1 (81\%). Vectors of fungi, AM fungi, and Gram- all positively correlated with CV1, while the covariate for Gram+ is correlated with both CV1 and CV2 (Figure 3D). In crop year 2014, the community structure exhibited differences that discriminated WC and WW, from SW-WC and SW-WW along CV1 (94\%). However, vectors for T-PLFA and AM fungi were negatively correlated, while fungi, and Gram- bacteria were positively associated with CV1 (Figure 3E).

\section{DISCUSSION}

Dehydrogenase enzymes aid in the oxidation of soil organic matter and are considered good indicators of microbial activity (Garcia-Gil et al., 2000). However, crop rotation treatments had little effect on dehydrogenase enzyme activity (DEA) of soil associated with WC compared to WW. Activity of dehydrogenase was significantly greater in WW vs. WC at the first sampling, but no consistent pattern was observed for the remainder of the experiment. While DEA has been reported to be a suitable indicator of microbial activity

TABLE 3 | Absolute abundance (nmol/g) of microbial lipid groups at 0-5 cm depth from each crop year (2009-2014).

\begin{tabular}{|c|c|c|c|c|c|c|}
\hline Crop year & Treatment & Fungi & AM fungi & Gram- & Gram+ & Total \\
\hline \multirow[t]{4}{*}{2009} & WC & $1.59 \mathrm{AB}$ & $0.41 \mathrm{~A}$ & $3.04 \mathrm{~A}$ & $4.01 \mathrm{~A}$ & $16.14 \mathrm{~A}$ \\
\hline & WW & $1.83 \mathrm{~A}$ & $0.52 \mathrm{~A}$ & $2.27 \mathrm{~A}$ & $4.16 \mathrm{~A}$ & $15.47 \mathrm{~A}$ \\
\hline & SW-WC & $0.93 C$ & $0.09 \mathrm{~B}$ & $0.50 \mathrm{~B}$ & $1.61 \mathrm{~B}$ & 8.93 B \\
\hline & SW-WW & $1.35 \mathrm{BC}$ & $0.34 \mathrm{~A}$ & $0.66 \mathrm{~B}$ & $1.82 \mathrm{~B}$ & $11.29 \mathrm{~B}$ \\
\hline \multirow[t]{4}{*}{2010} & WC & $1.08 \mathrm{AB}$ & $0.13 \mathrm{~B}$ & $0.68 \mathrm{~B}$ & $1.50 \mathrm{~B}$ & $9.01 \mathrm{~A}$ \\
\hline & WW & $1.63 \mathrm{~A}$ & $0.22 \mathrm{AB}$ & $0.80 \mathrm{~B}$ & $1.79 \mathrm{~B}$ & $10.09 \mathrm{~A}$ \\
\hline & SW-WC & 0.76 B & $0.23 \mathrm{~A}$ & $2.12 \mathrm{~A}$ & $3.70 \mathrm{~A}$ & $14.01 \mathrm{~B}$ \\
\hline & SW-WW & $1.39 \mathrm{AB}$ & $0.29 \mathrm{~A}$ & $1.85 \mathrm{~A}$ & $3.51 \mathrm{~A}$ & $13.79 \mathrm{~B}$ \\
\hline \multirow[t]{4}{*}{2012} & WC & $0.67 \mathrm{AB}$ & 0.12 BC & $0.72 \mathrm{~A}$ & 1.49 B & 8.43 B \\
\hline & WW & $1.13 \mathrm{~A}$ & $0.41 \mathrm{~A}$ & $1.13 \mathrm{~B}$ & $1.98 \mathrm{~A}$ & $20.70 \mathrm{~A}$ \\
\hline & SW-WC & $0.41 \mathrm{~B}$ & $0.07 C$ & $0.50 \mathrm{~B}$ & 1.08 B & 7.25 B \\
\hline & SW-WW & $0.56 \mathrm{AB}$ & $0.18 \mathrm{~B}$ & $0.66 \mathrm{~B}$ & $1.13 \mathrm{~B}$ & 8.16 B \\
\hline \multirow[t]{4}{*}{2013} & WC & $1.10 \mathrm{~B}$ & $0.19 \mathrm{~B}$ & $1.22 B$ & $3.01 \mathrm{~B}$ & $11.93 \mathrm{~B}$ \\
\hline & WW & $2.10 \mathrm{AB}$ & $0.54 \mathrm{~A}$ & $2.43 \mathrm{~A}$ & $5.07 \mathrm{~A}$ & $18.11 \mathrm{~A}$ \\
\hline & SW-WC & 1.56 B & $0.30 \mathrm{~B}$ & $1.75 \mathrm{AB}$ & $3.54 \mathrm{~B}$ & 14.24 B \\
\hline & SW-WW & $3.15 \mathrm{~A}$ & $0.54 \mathrm{~A}$ & $2.14 \mathrm{~A}$ & $5.51 \mathrm{~A}$ & 19.75 A \\
\hline \multirow[t]{4}{*}{2014} & WC & $1.10 \mathrm{~B}$ & $0.28 \mathrm{~A}$ & $2.73 \mathrm{~A}$ & $5.04 \mathrm{~A}$ & $16.87 \mathrm{~A}$ \\
\hline & WW & $2.01 \mathrm{~A}$ & $0.35 \mathrm{~A}$ & $3.01 \mathrm{~A}$ & $5.32 \mathrm{~A}$ & $18.96 \mathrm{~A}$ \\
\hline & SW-WC & $1.23 \mathrm{AB}$ & $0.23 \mathrm{~A}$ & $1.02 \mathrm{~B}$ & 3.52 B & $12.18 \mathrm{~B}$ \\
\hline & SW-WW & $1.57 \mathrm{AB}$ & $0.34 \mathrm{~A}$ & $1.29 \mathrm{~B}$ & 3.63 B & $13.62 \mathrm{~B}$ \\
\hline
\end{tabular}

Values are least square means of individual crop years $(n=24)$. Bold italics indicate significant difference between WC and WW, or SW-WC and SW-WW $(p \leq 0.05)$. 

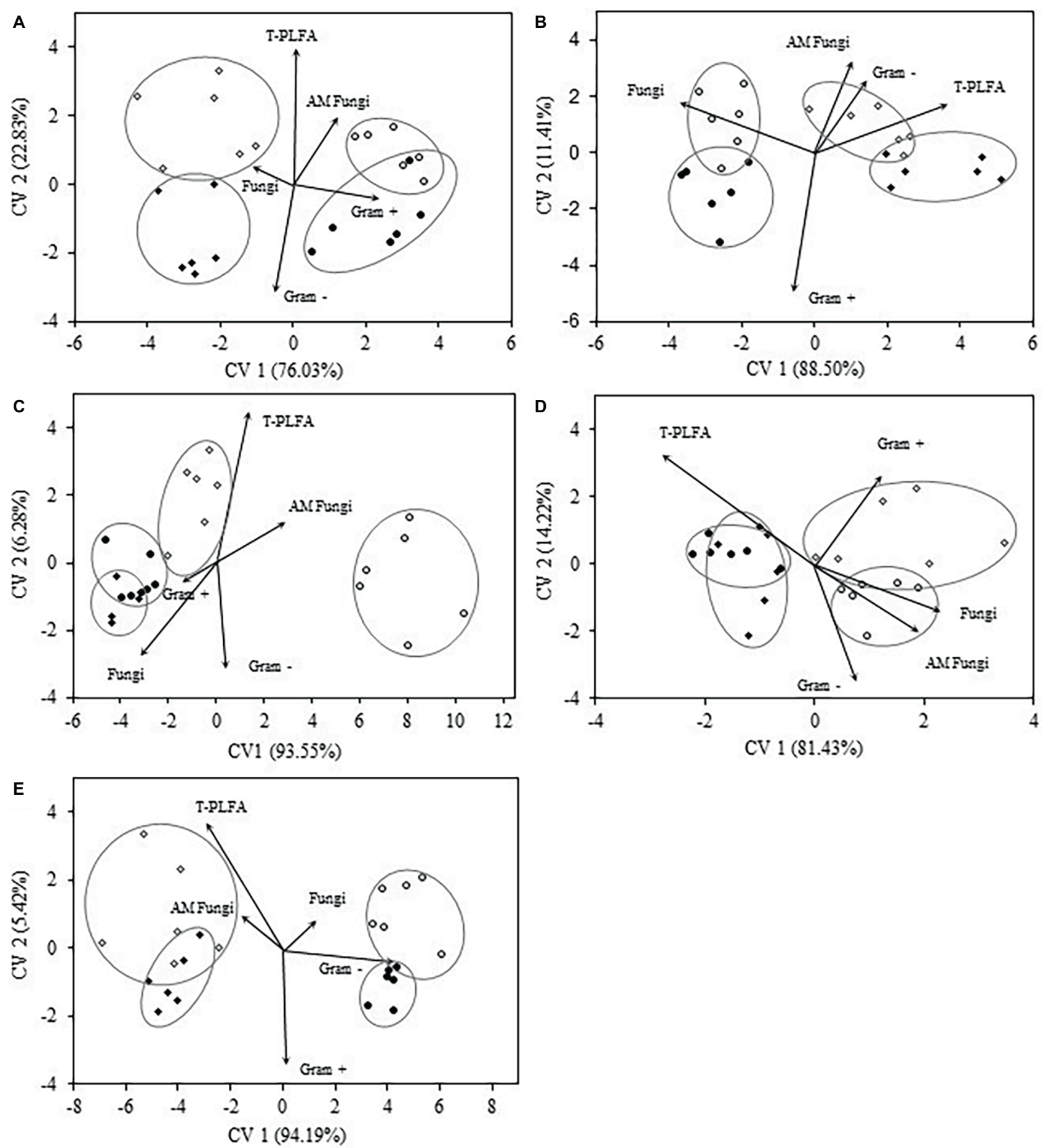

FIGURE 3 | Canonical variates for lipid biomarker groups. Biomarker groups and total PLFA (T-PLFA) of the 0-5 cm depth for crop years 2009 (A), 2010 (B), 2012 (C), 2013 (D), and 2014 (E). Vectors represent standardized canonical coefficients and indicate the contribution of each biomarker group to each canonical variate. Each sample point is represented and cluster by crop treatment. Each cluster is accompanied by a mean ellipse at the $95 \%$ confidence interval (treatments groups that differ significantly have confidence ellipses that do not intersect).

(Garcia-Gil et al., 2000), no differences in DEA associated with management practices have been reported (Kennedy and Schillinger, 2006; Pritchett et al., 2010). The intercellular nature of dehydrogenase and relation to the metabolic activity of soil microorganisms (Tabatabai and Dick, 2002) could explain why this enzyme assay may not be as responsive to immediate changes in management practices (Pritchett et al., 2010). In a similar study, differences in DEA were not observed until 
the third and fourth years of crop rotation and residue management (Schillinger et al., 2010).

Unlike DEA, crop rotation treatment did impact $\beta$-glucosidase activity. The rotation that included WW significantly increased BGA compared to WC. Because $\beta$-glucosidase enzymes are produced by bacteria and fungi, they are commonly found in agricultural soils (Shewale, 1981). Waldrop et al. (2000) showed a correlation between BGA and the microbial community composition of soils determined by PLFA. Hansen et al. (2018) reported that greater rhizosphere BGA in WW compared to WC was typically accompanied by greater abundance of total microbial biomass and individual biomarker groups in WW over WC. Knight and Dick (2004) previously reported correlations between microbial biomass and BGA. Therefore, reduced BGA suggests that WC led to reduced microbial biomass. This supports the results of 25.3 and $15.03 \%$ greater microbial biomass (T-PLFA) in WW vs. WC and SW-WW vs. SW-WC, respectively. While $\beta$-glucosidase enzymes are associated with bacteria and fungi, correlations between BGA and soil fungi have been reported (Hayano and Tubaki, 1985; Acosta-Martinez et al., 2007). Therefore, differences in BGA could correspond to soil fungal abundance which was significantly greater for WW vs. WC and SW-WW vs. SW-WC at both $0-5$ and 5-10 cm depths.

While the results of this study indicate that fungal biomass contributes less to the total microbial biomass than bacteria, the influence of fungi is thought to be substantial. Among treatments, microbial lipid biomarkers indicate greater fungal abundance and AM fungi abundance in the WW compared to the WC treatments and supports the findings of Kirkegaard et al. (2000), who determined that high levels of GSL in the root tissues of canola grown in, or added to, soil are correlated with greater suppression of soil fungi. The differences in community structure between $\mathrm{WC}$ and $\mathrm{WW}$ treatments are well differentiated, indicating a shift in in the community from that which has developed under the historical rotations. The covariates of fungi, AM fungi, and T-PLFA are responsible for the discrimination in communities among treatments, with the covariates of bacteria having either a negative or null correlation with both canonical variates. Results of differentiated microbial communities agree with the research of Lay et al. (2018) who reported that the canola microbiome was significantly different from those of wheat and pea. Fungal populations in our study were significantly different, while the abundance of bacterial biomarkers was not significantly different but often lower in WC. This reduced influence on bacteria was also observed by $\mathrm{Hu}$ et al. (2015) who reported a decrease in fungal populations and a shift in the fungal community following additions of ITC, while less influence was observed in bacterial populations. Additionally, Smith and Kirkegaard (2002) determined that while ITC derived from canola roots negatively impacted both bacteria and fungi, bacteria were able to survive higher concentrations compared to fungi.

The microbial community of each individual crop year compared to the recorded yield data reveals some corresponding patterns in both abundance and community structure. These patterns could potentially explain the yield response of the subsequent SW crop. In crop years 2010 and 2013, SW yields were not significantly different (Schillinger and Paulitz, 2018), and in both cases, the community structure as well as the vector for AM fungi were positively correlated with CV1. The SW yield difference in 2010 was less than $2 \%$, and there were no significant differences for any biomarker that year. However, biomarkers for 2013 were significantly different and may explain a yield difference of $9 \%$ of WW-SW over WC-SW.

Spring wheat yields in 2009, 2012, and 2014 were significantly reduced in SW-WC vs. SW-WW by $24.5,28.1$, and $37.9 \%$, respectively (Schillinger and Paulitz, 2018). Averaged over the 5 years, highly significant differences in SW yield following WW vs. WC had $p<0.0001$ (Schillinger and Paulitz, 2018). Microbial community structure for SW in 2009, 2012, and 2014 differentiates SW-WC from WW along CV1 and is negatively correlated with both $\mathrm{CV} 1$ and CV2. The only biomarker at the $0-5 \mathrm{~cm}$ depth significantly reduced in SW-WC for 2009 and 2012 was AM fungi and was significant in 2014 at $p \leq 0.10(p=0.0962)$. These three crop years also showed significantly reduced abundance for AM fungi in SW-WC at the 5-10 cm depth. In Northern Australia, reduced wheat yields in plots previously planted to canola were due to poor colonization with AM fungi (Owen et al., 2010), indicated by a significant correlation between yield of wheat and the levels of AM fungi following pre-crop treatments. In our study, 2011 had the highest overall WW yield and was the only year that WW was the only treatment positively correlated with CV1 (94\%), with vectors for AM fungi and T-PLFA reflecting the largest contributions. Contrasting results from southern Australia indicate that AM fungi were not related to either positive or negative yield responses but rather residual $\mathrm{N}$, water, and disease legacies (Kirkegaard and Ryan, 2014). The yield results reported by Schillinger and Paulitz (2018) were preceded by extensive analysis including residual $\mathrm{N}, \mathrm{P}, \mathrm{S}$, and soil water, foliar and root diseases, weeds, and root-lesion nematodes. With these variables eliminated as the cause for the yield response, the results of Owen et al. (2010) appear to align with our findings.

Biomarkers identified as fungal consistently contained a measurable subset of mycorrhizal-related biomarkers. This suggests that our soil samples contained a resident population of mycorrhizae. If native populations of mycorrhizae exist, observed historical yields may be partially affected by mycorrhizal associations. Most crop species are considered mycorrhizal hosts in field situations and, therefore, possess a strategy that improves plant productivity (Smith et al., 2011). Under dryland conditions in the Pacific Northwest, native mycorrhizal colonization of wheat roots ranged from 13 to 26\% (Mohammad et al., 1998) and increased to $51 \%$ with inoculation accompanied by a $25 \%$ increase in wheat grain yield. The findings presented here have confirmed reduced mycorrhizal biomarkers following canola. With reduced mycorrhizal abundance, the potential for colonization also declines. While that may be the case, contrasting reports argue that current wheat cultivars do not always form AM fungi relationships (Singh et al., 2012), modern breeding programs have reduced the responsiveness to AM fungi (Zhu et al., 2001), or response of subsequent crops was not 
related to AM fungal colonization (Kirkegaard and Ryan, 2014). However, our results presented here extend beyond the influence of AM fungi. Total PLFA and fungi across all years had significantly greater abundance in WW and SW-WW as well as positive correlation with the community structure.

Observed rotational effects of WC were limited to the subsequent SW crop. While the short-term effect was evident, the long-term influence was negligible. Differences in microbial biomass and microbial community composition as well as enzyme activities were not significant in the third year of the rotation, suggesting a recovery of soil biological conditions (data not shown). In 2 years of the 6-year study, SW was planted back-to-back (i.e., WC-SW-SW and WW-SW-SW) to determine the duration of the yield decline. No difference in SW yields was reported for these years (Schillinger and Paulitz, 2018), suggesting a short-lived rotation effect. Farmers in the region where this study was conducted have largely transitioned to planting spring canola in a WW-spring canola (SC)-NTF rotation. To date, farmers have observed no reduction in WW yield in the WW-SC-NTF compared with WW-SW-NFT rotation. Therefore, a 13-month fallow period following canola appears to resolve potential negative canola rotation effects.

\section{CONCLUSION}

Crop rotation and diversification are generally recognized as management tools to enhance soil health in agroecosystems. A relevant objective for the use of rotation crops is to increase the performance of subsequent crops. The degree of influence on soil biological properties and crop productivity is, however, crop specific. Results showed that WC generally led to decreased microbial biomass compared to WW. Notably, fungi and AM fungi were more prone than bacteria to the apparent

\section{REFERENCES}

Acosta-Martinez, V., Mikha, M. M., and Vigil, M. F. (2007). Microbial communities and enzyme activities in soils under alternative crop rotations compared to wheat-fallow for the Central Great Plains. Appl. Soil Ecol. 37, 41-52. doi: 10.1016/j.apsoil.2007.03.009

Alvey, S., Yang, C. H., Buerkert, A., and Crowley, D. (2003). Cereal/legume rotation effects on rhizosphere bacterial community structure in West African soils. Biol. Fertil. Soils 37, 73-82. doi: 10.1007/s00374-002-0573-2

Bååth, E. (2003). The use of neutral lipid fatty acids to indicate the physiological conditions of soil fungi. Microb. Ecol. 45, 373-383. doi: 10.1007/s00248-003-2002-y

Bais, H. P., Weir, T. L., Perry, L. G., Gilroy, S., and Vivanco, J. M. (2006). The role of root exudates in rhizosphere interactions with plants and other organisms. Annu. Rev. Plant Biol. 57, 233-266. doi: 10.1146/annurev.arplant.57. 032905.105159

Bending, G. D., and Lincoln, S. D. (2000). Inhibition of soil nitrifying bacteria communities and their activities by glucosinolate hydrolysis products. Soil Biol. Biochem. 32, 1261-1269. doi: 10.1016/S0038-0717(00)00043-2

Bennett, A. J., Hilton, S., Bending, G. D., Chandler, D., and Mills, P. (2014). Impact of fresh root material and mature crop residues of oilseed rape (Brassica napus) on microbial communities associated with subsequent oilseed rape. Biol. Fertil. Soils 50, 1267-1279. doi: 10.1007/s00374-014-0934-7

Bligh, E. G., and Dyer, W. J. (1959). A rapid method of total lipid extraction and purification. Can. J. Biochem. Physiol. 37, 911-917. doi: 10.1139/y59-099 canola rotation effect. Declines in viable microbial biomass could interrupt key microbial processes related to nutrient and water acquisition essential for optimal crop productivity. While effects on the microbial community were observed within the initial WC and subsequent SW crops, the long-term effects (i.e., after 1 year) were negligible. Data from this study have helped regional farmers adjust their sequence of planting canola in wheat-based rotations that allow for continued crop diversification and to maintain optimum crop yield potential.

\section{AUTHOR CONTRIBUTIONS}

WS, TP, and $\mathrm{JH}$ designed the experiment. $\mathrm{JH}$ performed all laboratory analysis, statistical analysis, evaluated the data, and drafted the manuscript. JH, WS, TP, and TS all contributed to the final version of the manuscript.

\section{ACKNOWLEDGMENTS}

Support from the Northwest Sustainable Agroecosystems Research Unit, USDA-Agricultural Research Service and from Dr. Ann Kennedy is gratefully acknowledged. Additional funding was provided by the USDA/NIFA through Hatch projects 1017286 and 1014527 and the Washington Oilseeds Cropping Systems Project. The technical assistance of John Jacobsen, Bruce Sauer, Steve Schofstoll, Brian Fode, Trang Uyan Pham, and Samantha Crow is greatly appreciated. We thank collaborating farmer Hal Johnson for his donation of land, time, and equipment. The USDA and WSU are equal opportunity providers and employers. Mention of trade names or commercial products in this publication is solely for providing specific information and does not imply recommendation or endorsement.

Bossio, D. A., Scow, K. M., Gunapala, N., and Graham, K. J. (1998). Determinants of soil microbial communities: effects of agricultural management, season, and soil type on phospholipid fatty acid profiles. Microb. Ecol. 36, 1-12. doi: $10.1007 / \mathrm{s} 002489900087$

Brockett, B. F., Prescott, C. E., and Grayston, S. J. (2012). Soil moisture is the major factor influencing microbial community structure and enzyme activities across seven biogeoclimatic zones in western Canada. Soil Biol. Biochem. 44, 9-20. doi: 10.1016/j.soilbio.2011.09.003

Brown, P. B., and Morra, M. J. (1997). Control of soil-borne plant pests using glucosinolate-containing plants. Adv. Agron. 61, 167-231. doi: 10.1016/ S0065-2113(08)60664-1

Bünemann, E. K., Marscher, P., Smernik, R. J., Conyers, M., and McNeill, A. M. (2008). Soil organic phosphorus and microbial community composition as affected by 26 years of different management strategies. Biol. Fertil. Soils 44, 717-726. doi: 10.1007/s00374-007-0254-2

Buyer, J. S., and Sasser, M. (2012). High throughput phospholipid fatty acid analysis of soils. Appl. Soil Ecol. 61, 127-130. doi: 10.1016/j.apsoil.2012.06.005

Buyer, J. S., Teasdale, J. R., Roberts, D. P., Zasada, I. A., and Maul, J. E. (2010). Factors affecting soil microbial community structure in tomato cropping systems. Soil Biol. Biochem. 42, 831-841. doi: 10.1016/j.soilbio.2010.01.020

Dong, H. Y., Kong, C. H., Wang, P., and Huang, Q. L. (2014). Temporal variation of soil friedelin and microbial community under different land uses in a long-term agroecosystem. Soil Biol. Biochem. 69, 275-281. doi: 10.1016/j.soilbio.2013.11.016 
Drijber, R. A., Doran, J. W., Parkhurst, A. M., and Lyon, A. M. (2000). Changes in soil microbial community structure with tillage under long-term wheatfallow management. Soil Biol. Biochem. 32, 1419-1430. doi: 10.1016/ S0038-0717(00)00060-2

Duchicela, J., Sullivan, T. S., Bontti, E., and Bever, J. D. (2013). Soil aggregate stability increase is strongly related to fungal community succession along an abandoned agricultural field chronosequence in the Bolivian Altiplano. J. Appl. Ecol. 50, 1266-1273. doi: 10.1111/1365-2664.12130

Finney, D. M., Buyer, J. S., and Kaye, J. P. (2017). Living cover crops have immediate impacts on soil microbial community structure and function. J. Soil Water Conserv. 72, 361-373. doi: 10.2489/jswc.72.4.361

Frostegård, A., and Bååth, E. (1996). The use of phospholipid fatty acid analysis to estimate bacterial and fungal biomass in soil. Biol. Fertil. Soils 22, 59-65. doi: $10.1007 /$ BF00384433

Garcia-Gil, J. C., Plaza, C., Soler-Rovira, P., and Polo, A. (2000). Long-term effects of municipal solid waste compost application on soil enzyme activities and microbial biomass. Soil Biol. Biochem. 32, 1907-1913. doi: 10.1016/ S0038-0717(00)00165-6

Gil, S. V., Meriles, J., Conforto, C., Basanta, M., Radl, V., Hagn, A., et al. (2011). Response of soil microbial communities to different management practices in surface soils of a soybean agroecosystem in Argentina. Eur. J. Soil Biol. 47, 55-60. doi: 10.1016/j.ejsobi.2010.11.006

Graf, F., and Frei, M. (2013). Soil aggregate stability related to soil density, root length, and mycorrhiza using site-specific Alnus incana and Melanogaster variegatus. Ecol. Eng. 57, 314-323. doi: 10.1016/j.ecoleng.2013.04.037

Grayston, S. J., Wang, S., Campbell, C. D., and Edwards, A. (1998). Selective influence of plant species on microbial diversity in the rhizosphere. Soil Biol. Biochem. 30, 369-378. doi: 10.1016/S0038-0717(97)00124-7

Griffiths, B. S., and Philippot, L. (2013). Insights into the resistance and resilience of the soil microbial community. FEMS Microbiol. Rev. 37, 112-129. doi: 10.1111/j.1574-6976.2012.00343.x

Hansen, J. C., Schillinger, W. F., Sullivan, T. S., and Paulitz, T. C. (2018). Rhizosphere microbial communities of canola and wheat at six paired field sites. Appl. Soil Ecol. 130, 185-193. doi: 10.1016/j.apsoil.2018.06.012

Haramoto, E. R., and Gallandt, E. R. (2004). Brassica cover cropping for weed management: a review. Renew Agric. Food Syst. 19, 187-198. doi: 10.1079/ RAFS200490

Hayano, K., and Tubaki, K. (1985). Origin and properties of $\beta$-glucosidase activity of tomato-field soil. Soil Biol. Biochem. 17, 553-557. doi: 10.1016/00380717(85)90024-0

Hilton, S., Bennett, A. J., Chandler, D., Mills, P., and Bending, G. D. (2018). Preceding crop and seasonal effects influence fungal, bacterial and nematode diversity in wheat and oilseed rape rhizosphere and soil. Appl. Soil Ecol. 126, 34-46. doi: 10.1016/j.apsoil.2018.02.007

Hilton, S., Bennett, A. J., Keane, G., Bending, G. D., Chandler, D., Stobart, R., et al. (2013). Impact of shortened crop rotation of oilseed rape on soil and rhizosphere microbial diversity in relation to yield decline. PLoS One 8:e59859. doi: 10.1371/journal.pone.0059859

Hu, P., Hollister, E. B., Somenahally, A. C., Hons, F. M., and Gentry, T. J. (2015). Soil bacterial and fungal communities respond differently to various isothiocyanates added for biofumigation. Front. Microbiol. 5:729. doi: 10.3389/ fmicb.2014.00729

JMP (1989-2007). JMP Version 12.1. (Cary, NC: SAS Institute Inc.).

Kaur, A., Chaudhary, A., Kaur, A., Choudhary, R., and Kaushik, R. (2005). Phospholipid fatty acid-A bioindicator of environment monitoring and assessment in soil ecosystem. Curr. Sci. 89, 1103-1112.

Kennedy, A. C., and Papendick, R. I. (1995). Microbial characteristics of soil quality. J. Soil Water Conserv. 50, 243-248.

Kennedy, A. C., and Schillinger, W. F. (2006). Soil quality and water intake in traditional-till vs. no-till paired farms in Washington's Palouse region. Soil Sci. Soc. Am. J. 70, 940-949. doi: 10.2136/sssaj2005.0160

Kirkegaard, J. A., and Ryan, M. H. (2014). Magnitude and mechanisms of persistent crop sequence effects on wheat. Field Crop Res. 164, 154-165. doi: 10.1016/j.fcr.2014.05.005

Kirkegaard, J. A., and Sarwar, M. (1999). Glucosinolate profiles of Australian canola (Brassica napus annua L.) and Indian mustard (Brassica juncea L.) cultivars: implications for biofumigation. Aust. J. Agric. Res. 50, 315-324. doi: 10.1071/A98124
Kirkegaard, J. A., Sarwar, M., Wong, P. T. W., Mead, A., Howe, G., and Newell, M. (2000). Field studies on the biofumigation of take-all by Brassica break crops. Aust. J. Agric. Res. 51, 445-456. doi: 10.1071/AR99106

Knight, T. R., and Dick, R. P. (2004). Differentiating microbial and stabilized $\beta$-glucosidase activity relative to soil quality. Soil Biol. Biochem. 36, 2089-2096. doi: 10.1016/j.soilbio.2004.06.007

Koenig, R. T. (2005). Dryland winter wheat: Eastern Washington nutrient management guide. Pullman, WA: Washington State University Extension. Available at: https://gcc01.safelinks.protection.outlook.com/?url=http\%3A\% 2F\%2Fcru.cahe.wsu.edu\%2FCEPublications\%2FEB1987E\%2FEB1987E. pdf\&amp;data $=01 \% 7 \mathrm{C} 01 \% 7 \mathrm{C} \% 7 \mathrm{C} 88 \mathrm{~d} 66005406 \mathrm{c} 467 \mathrm{a} 995 \mathrm{f} 08 \mathrm{~d} 6 \mathrm{f} 699 \mathrm{a} 548 \%$ 7Ced5b36e701ee4ebc867ee03cfa0d4697\%7C1\&amp;sdata=5P5KRvAzG2IyV Y22ypvgYWFa4yoxxoEFH32KIUKMTL0\%3D\&amp;reserved=0

Koide, R. T., and Schneider, A. (1992). Regulation of the vesicular-arbuscular mycorrhizal symbiosis. Annu. Rev. Plant Physiol. Plant Mol. Biol. 143, 557-581. doi: 10.1146/annurev.pp.43.060192.003013

Kong, C. H., Wang, P., Zhao, H., Xu, X. H., and Zhu, Y. D. (2008). Impact of allelochemical exuded from allelopathic rice on soil microbial community. Soil Biol. Biochem. 40, 1862-1869. doi: 10.1016/j.soilbio.2008.03.009

Ladygina, N., and Hedlund, K. (2010). Plant species influence microbial diversity and carbon allocation in the rhizosphere. Soil Biol. Biochem. 42, 162-168. doi: 10.1016/j.soilbio.2009.10.009

Larkin, R. P., and Honeycutt, C. W. (2006). Effects of different 3-year cropping systems on soil microbial communities and Rhizoctonia diseases of potato. Phytopathology 96, 68-79. doi: 10.1094/PHYTO-96-0068

Lay, C. Y., Bell, T. H., Hamel, C., Harker, K. N., Mohr, R., Greer, C. W., et al. (2018). Canola root-associated microbiomes in the Canadian Prairies. Front. Microbiol. 9:1188. doi: 10.3389/fmicb.2018.01188

Lazcano, C., Gómez-Brandón, M., Revilla, P., and Domínguez, J. (2013). Short-term effects of organic and inorganic fertilizers on soil microbial community structure and function. Biol. Fertil. Soils 49, 723-733. doi: 10.1007/s00374-012-0761-7

Lorenzo, P., Pereira, C. S., and Rodríguez-Echeverría, S. (2013). Differential impact on soil microbes of allelopathic compounds released by the invasive Acacia dealbata link. Soil Biol. Biochem. 57, 156-163. doi: 10.1016/j. soilbio.2012.08.018

Lützow, M. V., Kögel-Knabner, I., Ekschmitt, K., Matzner, E., Guggenberger, G., Marschner, B., et al. (2006). Stabilization of organic matter in temperate soils: mechanisms and their relevance under different soil conditions-a review. Eur. J. Soil Sci. 57, 426-445. doi: 10.1111/j.1365-2389.2006.00809.x

Madan, R., Pankhurst, C., Hawke, B., and Smith, S. (2002). Use of fatty acids for identification of AM fungi and estimation of the biomass of AM spores in soil. Soil Biol. Biochem. 34, 125-128. doi: 10.1016/S0038-0717(01)00151-1

Marschner, P., Kandeler, E., and Marschner, B. (2003). Structure and function of the soil microbial community in a long-term fertilizer experiment. Soil Biol. Biochem. 35, 453-461. doi: 10.1016/S0038-0717(02)00297-3

Marschner, P., Yang, C. H., Lieberei, R., and Crowley, D. E. (2001). Soil and plant specific effects on bacterial community composition in the rhizosphere. Soil Biol. Biochem. 33, 1437-1445. doi: 10.1016/S0038-0717(01)00052-9

Matthiessen, J. N., and Kirkegaard, J. A. (2006). Biofumigation and enhanced biodegradation: opportunity and challenge in soilborne pest and disease management. Crit. Rev. Plant Sci. 25, 235-265. doi: 10.1080/07352680600611543

Mazzola, M., Hewavitharana, S. S., and Strauss, S. L. (2015). Brassica seed meal soil amendments transform the rhizosphere microbiome and improve apple production through resistance to pathogen reinfestation. Phytopathology 105, 460-469. doi: 10.1094/PHYTO-09-14-0247-R.

McLean, E. O. (1982). "Soil pH and lime requirement" in Methods of soil analysis, Part 2. Chemical and microbiological properties. ed. A. L. Page (Madison, WI: American Society of Agronomy), 199-224.

Minoshima, H., Jackson, L. E., Cavagnaro, T. R., Sánchez-Moreno, S., Ferris, H., Temple, S. R., et al. (2007). Soil food webs and carbon dynamics in response to conservation tillage in California. Soil Sci. Soc. Am. J. 71, 952-963. doi: 10.2136/sssaj2006.0174

Mohammad, M. J., Pan, W. L., and Kennedy, A. C. (1998). Seasonal mycorrhizal colonization of winter wheat and its effect on wheat growth under dryland conditions. Mycorrhiza 8, 139-144. doi: 10.1007/s005720050226

Morra, M. J., and Kirkegaard, J. A. (2002). Isothyocyanate release from soilincorporated Brassica tissue. Soil Biol. Biochem. 34, 1683-1690. doi: 10.1016/ S0038-0717(02)00153-0 
NRCS. (2018). Web soil survey. Available at: https://websoilsurvey.sc.egov.usda. gov/App/WebSoilSurvey.aspx (Accessed June, 2018).

O'Donnell, A. G., Seasman, M., Macrar, A., Waite, I., and Davies, J. T. (2001). Plants and fertilizers as drivers of change in microbial community structure and functions. Plant Soil 232, 135-145. doi: 10.1023/A:1010394221729

Olsson, P. A. (1999). Signature fatty acids provide tools for determination of the distribution and interactions of mycorrhizal fungi in soil. FEMS Microbiol. Ecol. 29, 303-310. doi: 10.1111/j.1574-6941.1999.tb00621.x

Orwin, K. H., Dickie, I. A., Holdaway, R., and Wood, J. R. (2018). A comparison of the ability of PLFA and 16S rRNA gene metabarcoding to resolve soil community change and predict ecosystem functions. Soil Biol. Biochem. 117, 27-35. doi: 10.1016/j.soilbio.2017.10.036

Owen, K. J., Clewett, T. G., and Thompson, J. P. (2010). Pre-cropping with canola decreased Pratylenchus thornei populations, arbuscular mycorrhizal fungi, and yield of wheat. Crop Pasture Sci. 61, 399-410. doi: 10.1071/CP09345

Petersen, S. O., and Klug, M. J. (1994). Effects of sieving, storage, and incubation temperature on the phospholipid fatty acid profile of a soil microbial community. Appl. Environ. Microbiol. 60, 2421-2430.

Pollierer, M. M., Ferlian, O., and Scheu, S. (2015). Temporal dynamics and variation with forest type of phospholipid fatty acids in litter and soil of temperate forests across regions. Soil Biol. Biochem. 91, 248-257. doi: 10.1016/j. soilbio.2015.08.035

Pritchett, K., Kennedy, A. C., and Cogger, C. G. (2010). Management effects on soil quality in organic vegetable systems in western Washington. Soil Sci. Soc. Am. J. 75, 605-615. doi: 10.2136/sssaj2009.0294

Rumberger, A., and Marschner, P. (2003). 2-phenylethyl isothiocyanate concentration and microbial community composition in the rhizosphere of canola. Soil Biol. Biochem. 35, 445-452. doi: 10.1016/S0038-0717(02)00296-1

Sarwar, M., Kirkegaard, J. A., Wong, P. T., and Desmarchelier, J. M. (1998). Biofumigation potential of brassicas III: in vitro toxicity of isothiocyanates to soil-borne fungal pathogens. Plant Soil 201, 103-112. doi: 10.1023/ A:1004381129991

Schillinger, W. F., Kennedy, A. C., and Young, D. L. (2007). Eight years of annual no-till cropping in Washington's winter wheat-summer fallow region. Agric. Ecosyst. Environ. 120, 345-358. doi: 10.1016/j.agee.2006.10.017

Schillinger, W. F., Papendick, R. I., Guy, S. O., Rasmussen, P. E., and van Kessel, C. (2006). "Dryland cropping in the western United States" in Dryland agriculture. 2nd edn. Agronomy Monograph No. 23 eds. G. A. Peterson, P. W. Unger, and W. A. Payne, (Madison, WI: ASA/CSSA/SSSA), 365-393.

Schillinger, W. F., and Paulitz, T. C. (2018). Winter canola versus winter wheat rotation effects on subsequent wheat yield. Field Crop Res. 223, 26-32. doi: 10.1016/j.fcr.2018.04.002

Schillinger, W. F., Young, D. L., Paulitz, T. C., and Kennedy, A. C. (2010). Diverse no-till irrigated crop rotations instead of burning and plowing continuous wheat. Field Crop Res. 115, 39-49. doi: 10.1016/j.fcr.2009.10.001

Schmidt, M. W., Torn, M. S., Abiven, S., Dittmar, T., Guggenberger, G., Janssens, I. A., et al. (2011). Persistence of soil organic matter as an ecosystem property. Nature $7367,49-56$. doi: 10.1038/nature10386

Shewale, J. G. (1981). $\beta$-Glucosidase: its role in cellulase synthesis and hydrolysis of cellulose. Int. J. BioChemiPhysics 14, 435-443. doi: 10.1016/0020711X(82)90109-4

Siebers, M., Rohr, T., Ventura, M., Schütz, V., Thies, S., Kovacic, F., et al. (2018). Disruption of microbial community composition and identification of plant growth promoting microorganisms after exposure of soil to rapeseed-derived glucosinolates. PLoS One 13:e0200160. doi: 10.1371/journal.pone.0200160

Singh, A. K., Hamel, C., DePauw, R. M., and Knox, R. E. (2012). Genetic variability in arbuscular mycorrhizal fungi compatibility supports the selection of durum wheat genotypes for enhancing soil ecological services and cropping systems in Canada. Can. J. Microbiol. 58, 293-302. doi: 10.1139/w11-140

Smith, S. E., Jakobsen, I., Gronlund, M., and Smith, F. M. (2011). Roles of arbuscular mycorrhizas in plant phosphorus nutrition. Plant Physiol. 156, 1050-1057. doi: 10.1104/pp.111.174581

Smith, B. J., and Kirkegaard, J. A. (2002). In vitro inhibition of soil microorganisms by 2-phenylethyl isothiocyanate. Plant Pathol. 51, 585-593. doi: 10.1046/j.13653059.2002.00744.x
Smith, B. J., Kirkegaard, J. A., and Howe, G. N. (2004). Impact of Brassica break crops on soil biology and yield of following wheat crops. Aust. J. Agric. Res. 55, 1-11. doi: 10.1071/AR03104

Smith, A. P., Marin-Spiotta, E., and Balser, T. (2015). Successional and seasonal variations in soil and litter microbial community structure and function during tropical post agricultural forest regeneration: a multiyear study. Glob. Chang. Biol. 21, 3532-3547. doi: 10.1111/gcb.12947

Tabatabai, M. A., and Dick, W. A. (2002). "Enzymes in soil: research and developments in measuring activities" in Enzymes in the environment: Activity, ecology, and applications. eds. R. G. Burns and R. P. Dick (New York: Marcel Dekker, Inc), 567-596.

Talbot, J. M., Bruns, T. D., Smith, D. P., and Peay, K. (2013). Independent roles of ectomycorrhizal and saprotrophic communities in soil organic matter decomposition. Soil Biol. Biochem. 57, 282-291. doi: 10.1016/j.soilbio. 2012.10.004

Tian, W., Wang, L., Li, Y., Zhuang, K., Li, G., Zhang, J., et al. (2015). Responses of microbial activity, abundance, and community in wheat soil after three years of heavy fertilization with manure-based compost and inorganic nitrogen. Agric. Ecosyst. Environ. 213, 219-227. doi: 10.1016/j.agee.2015.08.009

Valetti, L., Iriarte, L., and Fabra, A. (2016). Effect of previous cropping of rapeseed (Brassica napus L.) on soybean (Glycine max) root mycorrhization, nodulation, and plant growth. Eur. J. Soil Biol. 76, 103-106. doi: 10.1016/j. ejsobi.2016.08.005

van Dam, N. M., Tytgat, T. O., and Kirkegaard, J. A. (2009). Root and shoot glucosinolates: a comparison of their diversity, function and interactions in natural and managed ecosystems. Phytochem. Rev. 8, 171-186. doi: 10.1007/ s11101-008-9101-9

Vestal, J. R., and White, D. C. (1989). Lipid analysis in microbial ecology: quantitative approaches to the study of microbial communities. Bioscience 39, 535-541. doi: 10.2307/1310976

Waldrop, M. P., Balser, T. C., and Firestone, M. K. (2000). Linking microbial community composition to function in a tropical soil. Soil Biol. Biochem. 32, 1837-1846. doi: 10.1016/S0038-0717(00)00157-7

Walsh, K. D., Sanderson, D., Hall, L. M., Mugo, S., and Hills, M. J. (2014). Allelopathic effects of camelina (Camelina sativa) and canola (Brassica napus) on wild oat, flax and radish. Allelopathy 33, 83-96.

Xuan, D. T., Guong, V. T., Rosling, A., Alström, S., Chai, B., and Högberg, N. (2012). Different crop rotation systems as drivers of change in soil bacterial community structure and yield of rice, Oryza sativa. Biol. Fertil. Soils 48, 217-225. doi: 10.1007/s00374-011-0618-5

Zelles, L. (1997). Phospholipid fatty acid profiles in selected members of soil microbial communities. Chemosphere 35, 275-294. doi: 10.1016/S00456535(97)00155-0

Zelles, L. (1999). Fatty acid patterns of phospholipids and lipopolysaccharides in the characterization of microbial communities in soil: a review. Biol. Fertil. Soils 29, 111-129. doi: 10.1007/s003740050533

Zhang, B., Li, Y., Ren, T., Tian, Z., Wang, G., He, X., et al. (2014). Short-term effect of tillage and crop rotation on microbial community structure and enzyme activities of a clay loam soil. Biol. Fertil. Soils 50, 1077-1085. doi: 10.1007/s00374-014-0929-4

Zhu, Y. G., Smith, S. E., Barritt, A. R., and Smith, F. A. (2001). Phosphorus efficiencies and mycorrhizal responsiveness of old and modern wheat cultivars. Plant Soil 237, 249-255. doi: 10.1023/A:1013343811110

Conflict of Interest Statement: The authors declare that the research was conducted in the absence of any commercial or financial relationships that could be construed as a potential conflict of interest.

Copyright $\odot 2019$ Hansen, Schillinger, Sullivan and Paulitz. This is an open-access article distributed under the terms of the Creative Commons Attribution License (CC BY). The use, distribution or reproduction in other forums is permitted, provided the original author(s) and the copyright owner(s) are credited and that the original publication in this journal is cited, in accordance with accepted academic practice. No use, distribution or reproduction is permitted which does not comply with these terms. 